\title{
Development and Evaluation of Value Added Roasted Maize Flour
}

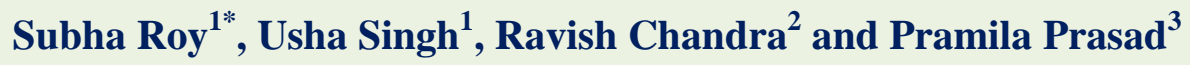 \\ ${ }^{1}$ Department of Food and Nutrition, College of Home Science, Dr. Rajendra Prasad Central \\ Agricultural University, Pusa, Samastipur (848125), India \\ ${ }^{2}$ Department of soil and Water Engineering, College of Agricultural Engineering, Dr. \\ Rajendra Prasad Central Agricultural University, Pusa, Samastipur (848125), India \\ ${ }^{3}$ Department of Home Science, Tilka Manjhi Bhagalpur University, Bhagalpur (848), India \\ *Corresponding author
}

\section{A B S T R A C T}

\section{Keywords}

Bihar, Roasted Maize Flour, Micronutrient, Value Added

Article Info

Accepted:

10 February 2018

Available Online:

10 March 2018
Maize is an important coarse grain cereal in Bihar. Nutrition security in rural areas of Bihar can be achieved through development and evaluation of value added roasted maize flour over traditional roasted maize flour. Value added roasted maize flour was rich source of macronutrients such as energy (351 kcal $/ 100 \mathrm{~g})$ and protein $(14.10 \mathrm{~g} / 100 \mathrm{~g})$ and micronutrient such as calcium (106mg/100g), carotene $\quad(139.50 \mu \mathrm{g} / 100 \mathrm{~g}), \quad$ Riboflavin $(0.13 \mathrm{mg} / 100 \mathrm{~g})$ and niacin $(2.25 \mathrm{mg} / 100 \mathrm{~g})$.

\section{Introduction}

Bihar is one of the largest maize growing states and the crop was grown primarily as a subsistence crop to meet food needs for a long time recently. Presently, Bihar is the third largest producer of maize in India, and it contributes about 8 per cent to the Indian maize production of 22.26 million tones (Mt) in 2012 - 2013 (Pandey, 2016).

Maize has worldwide significance as human food, animal feed and finds diversified uses in large number of industrial products (Kumar and Singh, 2003). Maize is deficient in niacin, pellagra prevalent among those who totally rely upon maize as a single daily food, is caused by the deficiency of this vitamin. Maize is low in calcium and the phosphrous occurs mostly as phytin.

The protein quality of maize evaluated for children recovering from protein energy malnutrition have been reported by various researchers.

Nitrogen retention from maize was significantly lower than milk at the same level of protein intake. Protein digestibility was 80 per cent for milk and 75 per cent for maize 
(Viteri et al., 1972). Because of the nutritional limitations in maize, many efforts (Bressani et al.,. 1978; Vivas et al., 1987 and Serna Saldivar et al., 1987, 1988a, 1988b) have been made to improve its protein quality through addition of amino acids of protein sources rich in amino acids. The present study was designed for the improvement of traditional maize diet of Bihar.

\section{Materials and Methods}

Development of value added roasted maize flour

The value added roasted maize flour were developed from cheap and locally available maize and pulses. It was reported in various study that cereal pulse combination (Bressani and Elias, 1974) and use of different processing methods helps to improve nutrients composition and availability (Sharma et al., 2015 and Khapre et al., 2016).

\section{Processing methods for maize and pulses}

\section{Maize}

Processing methods applied were soaking, alkali treatment and drying. At first, the grains of maize were soaked for 5 minutes in double amount of one per cent lime water. Heat treatment was given to it for 30 minutes and kept overnight. Next morning, the grain were washed for three to four times and sun dried (Kumari and Singh, 2013).

\section{Bengal gram whole}

Bengal gram whole was procured from the local market. For processing they were soaked in double amount of water for $6-7$ hours. Then soaked Bengal gram was spread on gunny bag and covered with another gunny bag. Once the sprouts came from pulses they were kept for drying in the sun.

\section{Preparation of value added roasted maize flour}

Ingredients and methods used for the development of the products were as follows:

\section{Value added roasted maize flour}

A total of 50 grams properly lime treated and sun dried maize and 50 grams processed Bengal gram were roasted till desirable flavor was obtained. Then they were mixed and ground to make fine roasted flour.

\section{Sensory evaluation of value added roasted} maize flour

Sensory quality of product was evaluated using a 9 - point hedonic scale.

Value added roasted maize flour was evaluated in the form of roasted maize flour balls, prepared with roasted maize flour, salt, finally chopped onion and green chilies and served for evaluation.

\section{Results and Discussion}

The value added roasted maize flour had higher macronutrients (energy, protein) as compared to traditional roasted maize flour (Table 1). The calorific value (per 100 gram) of value added roasted maize flour (351.00 kcal) was higher than traditional roasted maize flour $(343.00 \mathrm{kcal})$. Similarly the protein content has been found to be higher in case of value added roasted maize flour (14.10 g) in comparison with traditional roasted maize flour $(11.10 \mathrm{~g})$. The calcium and iron content was very high in value added roasted maize flour $(106.00 \mathrm{mg}$ calcium and $6.10 \mathrm{mg}$ iron per $100 \mathrm{~g}$ ) as compare to traditional roasted maize flour. Only the phosphorus content was low in value added roasted maize flour (330.0 $\mathrm{mg} / 100 \mathrm{~g}$ ) as compared to traditional roasted maize flour (348 mg / $100 \mathrm{~g}$ ). 
Table.1 Comparative analysis of proximate composition of traditional and value added roasted maize flour $(100 \mathrm{~g})$

\begin{tabular}{|l|c|c|}
\hline Nutrients & $\begin{array}{c}\text { Traditional roasted maize flour } \\
\text { Energy (kcal) }\end{array}$ & Value added roasted maize flour \\
\hline Protein (g) & 342.00 & 351.00 \\
\hline Calcium (mg) & 11.10 & 14.10 \\
\hline Phosphorus (mg) & 10.00 & 330.00 \\
\hline Iron (mg) & 348.00 & 6.10 \\
\hline Carotene (ug) & 2.00 & 139.50 \\
\hline Thiamine (mg) & 90.00 & 0.36 \\
\hline Riboflavin (mg) & 0.42 & 0.13 \\
\hline Niacin (mg) & 0.10 & 2.35 \\
\hline
\end{tabular}

Table. 2 Comparative analysis of essential amino acid content of traditional and value added roasted maize flour

\begin{tabular}{|c|c|c|}
\hline Essential amino acids & $\begin{array}{c}\text { Traditional roasted maize } \\
\text { flour }\end{array}$ & $\begin{array}{l}\text { Value added roasted maize } \\
\text { flour }\end{array}$ \\
\hline $\begin{array}{l}\text { Approximate Total Nitrogen } \\
(\mathrm{g} \text { per } 100 \mathrm{~g})\end{array}$ & 0.52 & 0.64 \\
\hline Lysine (g per 100 g) & 0.11 & 0.22 \\
\hline Tryptophan (g per 100 g) & 0.02 & 0.03 \\
\hline Methionine (g per $100 \mathrm{~g}$ ) & 0.06 & 0.06 \\
\hline Leucin (g per $100 \mathrm{~g}$ ) & 0.37 & 0.41 \\
\hline Isoleucine ( $\mathrm{g}$ per $\mathbf{1 0 0} \mathrm{g})$ & 0.13 & 0.19 \\
\hline
\end{tabular}


Table.3 Nutrient adequacy through value added roasted maize flour

\begin{tabular}{|c|c|c|c|c|c|c|c|c|c|c|c|c|}
\hline Nutrients & \multicolumn{3}{|c|}{ Preschool children (175g)* } & \multicolumn{3}{|c|}{ Pregnant women $(445 g) *$} & \multicolumn{3}{|c|}{ Lactating Women $(470 \mathrm{~g}) *$} & \multicolumn{3}{|c|}{ Elderly population $(460 \mathrm{~g}) *$} \\
\hline & A & B & $\mathrm{C}(\%)$ & A & B & $\mathrm{C}(\%)$ & A & B & $\mathrm{C}(\%)$ & A & B & $\mathrm{C}(\%)$ \\
\hline $\operatorname{Energy}(\mathrm{Kcal})$ & 1240.00 & 614.25 & 49.54 & 2175.00 & 1561.95 & 71.81 & 2425.00 & 1649.70 & 68.02 & 2425.000 & 1614.60 & 66.58 \\
\hline Protein (g) & 22.00 & 24.68 & 112.18 & 65.00 & 62.75 & 96.54 & 75.00 & 66.27 & 88.36 & 60.00 & 64.86 & 108.10 \\
\hline Calcium(mg) & 400.00 & 185.50 & 46.38 & 1000.00 & 471.70 & 47.17 & 1000.00 & 498.20 & 49.82 & 400.00 & 487.60 & 121.90 \\
\hline Iron(mg) & 12.00 & 10.68 & 89.00 & 38.00 & 27.15 & 71.45 & 30.00 & 28.67 & 95.57 & 28.00 & 28.06 & 100.21 \\
\hline Caro & 1600.00 & 244.13 & 15.26 & 2400.00 & 620.78 & 25.87 & 3800.00 & 655.65 & 17.25 & 2400.00 & 641.70 & 26.74 \\
\hline Thiamine (mg) & 0.60 & 0.63 & 105.00 & 1.10 & 1.60 & 145.45 & 1.20 & 1.69 & 140.83 & 1.20 & 1.66 & 138.33 \\
\hline Riboflavin (mg) & 0.70 & 0.22 & 31.43 & 1.30 & 0.56 & 43.07 & 1.40 & 0.59 & 42.14 & 1.40 & 0.58 & 41.43 \\
\hline Niacin (mg) & 8.00 & 4.11 & 51.38 & 14.00 & 10.46 & 74.71 & 16.00 & 11.05 & 69.06 & 16.00 & 10.81 & 67.56 \\
\hline
\end{tabular}

A: Recommended dietary allowances of vulnerable groups for different nutrients

B: Nutrinet composition of value added roasted maize flour as per recommended dietary allowances from cereal groups for vulnerable group

C: Nutrient Adequacy (\%) of value added roasted maize flour as per recommended dietary allowances among vulnerable groups

*Amount of cereal recommended for different vulnerable groups

(Source: Nutritive value of Indian foods, 1981, ICMR Publication)

Table.4 Per cent adequacy of nutrients with respect to $100 \mathrm{kcal}$ in value added roasted maize flour

\begin{tabular}{|c|c|c|c|c|c|c|c|c|}
\hline $\begin{array}{l}\text { Vulnerable } \\
\text { groups }\end{array}$ & & $\begin{array}{c}\text { Protein } \\
\text { (g) }\end{array}$ & $\begin{array}{l}\text { Calcium } \\
\text { (mg) }\end{array}$ & $\begin{array}{l}\text { Iron } \\
\text { (mg) }\end{array}$ & $\begin{array}{c}\text { Carotene } \\
(\mu g)\end{array}$ & $\begin{array}{c}\text { Thiamine } \\
\text { (mg) }\end{array}$ & $\begin{array}{c}\text { Riboflavin } \\
\text { (mg) }\end{array}$ & $\begin{array}{c}\text { Niacin } \\
(\mathrm{mg})\end{array}$ \\
\hline \multirow{3}{*}{$\begin{array}{l}\text { Preschool } \\
\text { children }\end{array}$} & RDA (100 kcal) & 1.77 & 32.26 & 0.97 & 129.03 & 0.05 & 0.06 & 0.65 \\
\hline & Value added roasted maize flour & 4.02 & 30.19 & 1.74 & 39.79 & 0.10 & 0.04 & 0.67 \\
\hline & Adequacy (\%) per $100 \mathrm{kcal}$ & 227.12 & 93.58 & 179.38 & 30.79 & 200.00 & 66.60 & 103.07 \\
\hline \multirow{3}{*}{$\begin{array}{l}\text { Pregnant } \\
\text { women }\end{array}$} & RDA (100 kcal) & 2.99 & 45.97 & 1.74 & 110.34 & 0.05 & 0.06 & 0.64 \\
\hline & Value added roasted maize flour & 4.02 & 30.19 & 1.74 & 39.79 & 0.10 & 0.04 & 0.67 \\
\hline & Adequacy (\%) per $100 \mathrm{kcal}$ & 134.45 & 65.67 & 100.00 & 36.02 & 200.00 & 66.60 & 104.69 \\
\hline \multirow{3}{*}{$\begin{array}{l}\text { Lactating } \\
\text { women }\end{array}$} & RDA (100 kcal) & 3.09 & 41.23 & 1.24 & 156.70 & 0.05 & 0.06 & 0.66 \\
\hline & Value added roasted maize flour & 4.02 & 30.19 & 1.74 & 39.79 & 0.10 & 0.04 & 0.67 \\
\hline & Adequacy (\%) per $100 \mathrm{kcal}$ & 130.09 & 73.22 & 140.32 & 25.36 & 200.00 & 66.60 & 101.52 \\
\hline \multirow[t]{3}{*}{ Elderly people } & RDA (100 kcal) & 2.45 & 16.49 & 1.15 & 98.97 & 0.05 & 0.06 & 0.66 \\
\hline & Value added roasted maize flour & 4.02 & 30.19 & 1.74 & 39.79 & 0.10 & 0.04 & 0.67 \\
\hline & Adequacy (\%) per $100 \mathrm{kcal}$ & 164.08 & 183.08 & 151.30 & 40.15 & 204.08 & 60.60 & 101.52 \\
\hline
\end{tabular}


Value added roasted maize flour was rich source of carotene $(139.50 \mu \mathrm{g} / 100 \mathrm{~g})$, riboflavin $(0.13 \mathrm{mg} / 100 \mathrm{~g})$ and niacin $(2.35 \mathrm{mg} / 100 \mathrm{~g})$ as compared to traditional roasted maize flour. Value added roasted maize flour was rich source of calcium, iron and carotene, it can be recommended for vulnerable groups (Table 2).

Methionine was found in equal amount in value added roasted maize flour and traditional roasted maize flour. The higher ratio of leucine to isoleucine in maize makes the maize protein unavailable to the body. In case of traditional roasted maize flour the leucine to isoleucine ratio is 2.85: 1 whereas it is 2.16: 1 in case of value added roasted maize flour.

Since the quality of protein determined by its amino acid composition the higher amount of lysine and tryptophan along with balanced ratio of leucine to isoleucine makes the value added roasted maize flour more nutritious and hence these are recommended for vulnerable groups.

It may be observed in Table 3 that the total protein content in traditional maize diets taken by preschool children, pregnant women, lactating women and elderly population is surplus by $83.50,8.36,4.85$ and 31.17 per cent respectively. Similarly the per cent of surplus thiamine content is 146 for preschool children and pregnant women and 151.02 for lactating women and elderly population each. On the contrary the calcium, iron, carotene, riboflavin and niacin are in deficit. Calcium content in traditional roasted maize flour is deficient by 91.09 per cent for preschool children, 93.69 per cent for pregnant women, 92.97 per cent for lactating women and 82.41 per cent for elderly population. Similarly percentage of iron is deficient by 40.20 for preschool children, 66.10 for pregnant women, 53.23 for lactating women and 49.57 for elderly population. This deficiency is higher in case of carotene for all age groups. The per cent of carotene deficiency is 79.61, $76.16,83.21$ and 73.42 for preschool children, pregnant women, lactating women and elderly population respectively. The deficiency of riboflavin in traditional roasted maize flour was 50.00 per cent for preschool children and pregnant women and 48.28 per cent for lactating women and elderly population. But the percentage of niacin deficiency is below 20.00 per cent for all age groups.

It can be observed in table 4 that the total protein content in value added roasted maize flour taken by preschool children, pregnant women, lactating women and elderly population surplus by $127.12,34.45,30.09$ and 64.08 per cent respectively. Similarly the percentage of thiamine content is surplus by 100.00 per cent for preschool children, pregnant women, lactating women and 104.08 for elderly population and the percentage of niacin was surplus by 3.07, 4.69, 1.52 and 1.52 per cent for preschool children, pregnant women, lactating women and elderly population. It is observed from table 3 and 4 that other nutrients like carotene and riboflavin were improved over traditional roasted maize flour.

\section{References}

Bressani, R., Elias, L.G. and Graham, J.E. (1978). Improvement of the protein quality of corn with soyabean protein. Adv. Exp. Med. Biol., 105. 29:65.

Bressani, R. and Elias, L. G. 1974. Legume foods. In A. M. Altschul, ed. New Protein Foods, 1(A): $231-297$.

Bressani, R., (1963). Effect of amino acid imbalance on nitrogen retention. Interrelationship between methionine, valine, isoleucine and threonine as supplements to corn proteins for dogs. J. Nutr., 79. 389-394. 
Bressani, R., Castillo, S. V. and Guzman, M.A. (1962). The nutritional evaluation of processed whole corn flour. J. Agric. Food Chem., 10. 308-312.

Food and Agricultural Organization, (2004). Maize in Human Nutrition. A series of nutrition studies.

Khapre, A. P., Shere, D. M. and Deshpandae, H. W. 2016. Studies on effect of roasting on nutritional and anti nutritional components of foxtail millet (Setaria italica). The Bioscan. 11(1): $177-179$.

Kumar, R. and Singh, N.P. 2003. Golden grain in transition. ICAR publication.

Kumari, P. and Singh, U. 2013. Effect of processing on nutritional status of food material for their use as supplementary food for pregnant women, Asian $\mathrm{J}$. Dairy \& Food Res. 32(2): 152 - 157.

Panday, A. 2016. Maize economy of Bihar, India; agro - climatic zone wise study (editorial) Ann Agric Crop Science, 1(4): 1017.

Serna - Saldivar, S.O., Knabe, D.A., Rooney, L.W. and Tanksley, T.D.Jr. (1987) effect of lime cooking on energy and protein digestibilities of maize and sorghum. Cereal Chem., 64. 247-252.
Serna - Saldivar, S.O., Knabe, D.A., Rooney, L.W., Tanksley, T.D.Jr. and Sproule, A.M. (1988b). Nutritional values of sorghum and maize tortillas. J. Cereal Sci., 7. 83-94.

Serna-Saldivar, S.O., Canett, R., Vargas, J., Gonzalez, M., Bedolla, S. and Medina, C. (1988a). Effect of soyabean and sesame addition on the nutritional value of maize and decorticated sorghum tortillas produced by extrusion cooking. Cereral Chem., 65. 44-48.

Sharma, Bindiya, Sharma, A., Bhat, A. and Kishor, A. 2015. Effect of germination on the chemical composition and nutritive value of maize grain, The Bioscan 10(3): 1017 - 1020.

Viteri, F., Martinez, C. and Bressani, R. (1972). Evaluation de la calidad proteinica del maiz comun, del maiz opaco-2y del maiz comun suplementado con aminoacidos y otras Fuentes de protein. In R. Bressani, J.E. Braham \& M. behar, eds. Mejormiento nutricional del maiz. INCAP Pub. L-3, 195-208. Guatemala, INCAP.

Vivas, N.E., Waniska, R.D. and Rooney, L.W. (1987). Effect of tortilla production on proteins in sorghum and maize. Cereal Chem., 64. 384-389.

\section{How to cite this article:}

Subha Roy, Usha Singh, Ravish Chandra and Pramila Prasad. 2018. Development and Evaluation of Value Added Roasted Maize Flour. Int.J.Curr.Microbiol.App.Sci. 7(03): 12241229. doi: https://doi.org/10.20546/ijcmas.2018.703.144 